\title{
CoBAGNPS: A Toolbox to Estimate Sediment Removal Efficiency of WASCoBs-Pipe Risers and Blind Inlets
}

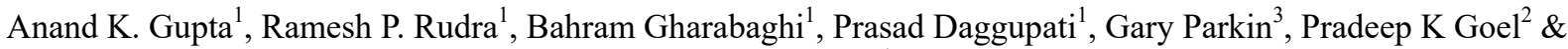 \\ Rituraj Shukla ${ }^{1}$ \\ ${ }^{1}$ School of Engineering, University of Guelph, Guelph, ON N1G 2W1 Canada \\ ${ }^{2}$ Ontario Ministry of the Environment and Climate Change, Etobicoke, ON M9P 3V6 Canada \\ ${ }^{3}$ School of Environmental Sciences, University of Guelph, Guelph, ON N1G 2W1 Canada \\ Correspondence: Anand K. Gupta, School of Engineering, University of Guelph, Guelph, ON N1G 2W1 Canada. \\ E-mail: gupta@uoguelph.ca
}

Received: June 20, 2018

Accepted: July 14, 2018

Online Published: September 19, 2018

doi:10.5539/enrr.v8n3p84

URL: https://doi.org/10.5539/enrr.v8n3p84

\begin{abstract}
Water and Sediment Control Basin (WASCoB) is an important BMP constructed along concentrated flow-paths (gullies etc.) to control the movement of water and sediment within a watershed. A WASCoB constitutes of a berm, surface inlets, and a drainage pipe to route water into a ditch. Direct runoff ponded behind the berm is routed through surface inlets into an underground drainage pipe. Therefore, surface inlets are an exceedingly important constituent of a WASCoB. Further pipe risers and blind inlets are the two most common type of surface inlets used. Therefore, maximum sediment removal efficiency of WASCoBs at a watershed-scale can be attained by the appropriate selection of a surface inlet, since the efficiency of a WASCoB is greatly impacted by the quantity of runoff and sediment leaving the surface inlet. In this study a toolbox was developed viz., CoBAGNPS to compute the sediment removal efficiency of pipe risers and blind inlets. A watershed-scale model (AGNPS) was integrated within the toolbox. Output files of the AGNPS model are fed as input files into the toolbox where a sediment routing module is programmed separately for pipe risers and blind inlets to obtain the sediment removal efficiency for each type of surface inlet. Further, the sediment routing module programmed for blind inlets integrates the AGNPS model with the HYDRUS 1-D model. The toolbox developed was applied to the Gully Creek watershed in Ontario, and the sediment load routed through pipe risers and blind inlets were compared.
\end{abstract}

\section{Keywords: CoBAGNPS, Pipe Riser, Blind Inlet, AGNPS}

\section{Introduction}

Non-point source (NPS) pollution culminating due to agricultural practices extensively pollutes water bodies globally (Das et al., 2006; Babin et al., 2016; Fraga et al., 2016; Fu et al., 2012; Malawska, 2008; Wang et al., 2016). Sediment is a significant NPS pollutant (Gharabaghi et al., 2006; Sebti \& Rudra, 2010). Transport of NPS pollutants over the land surface from agriculturally prevailing regions eventuates essentially by three primary mechanisms: rills, ephemeral gullies, and classical gullies (Daggupati et al., 2013). Therefore; precisely locating these gullies, followed by implementation of appropriate BMP is cardinal for the abatement of NPS pollution (Daggupati et al., 2011, 2013). BMPs could be constructed in a watershed either randomly or by strategic targeting (Tomer et al., 2010; Daggupati et al., 2011). Several studies have revealed that constructing BMPs randomly is not ideal for obtaining their maximum efficiency in mitigating NPS pollutants (Dillaha et al., 1988; Sprague \& Gronberg 2012; Tomer et al., 2010). Therefore, strategically identifying and prioritization of regions, followed by implementation of adequate BMPs is a crucial step for an effective watershed management (Diebel et al., 2008; Daggupati et al., 2011; Daggupati et al., 2013).

Water and Sediment Control Basin (WASCoB) is one such BMP designed specifically for impeding the development of concentrated gullies (Fiener et al., 2005; Her et al., 2017; Kovacic et al., 2006; Verstraeten \& Poesen, 2001). WASCoBs are constructed with an aim to alleviate transport of sediment and nutrients generated within farmlands; thereby impeding the formation of gullies by interrupting a watercourse (Her et al., 2016). 
Also, WASCoBs are normally constructed in agricultural watersheds. Berms (ponded area), surface inlets, and drainage system combined are commonly referred to as a WASCoB (Figure 1).

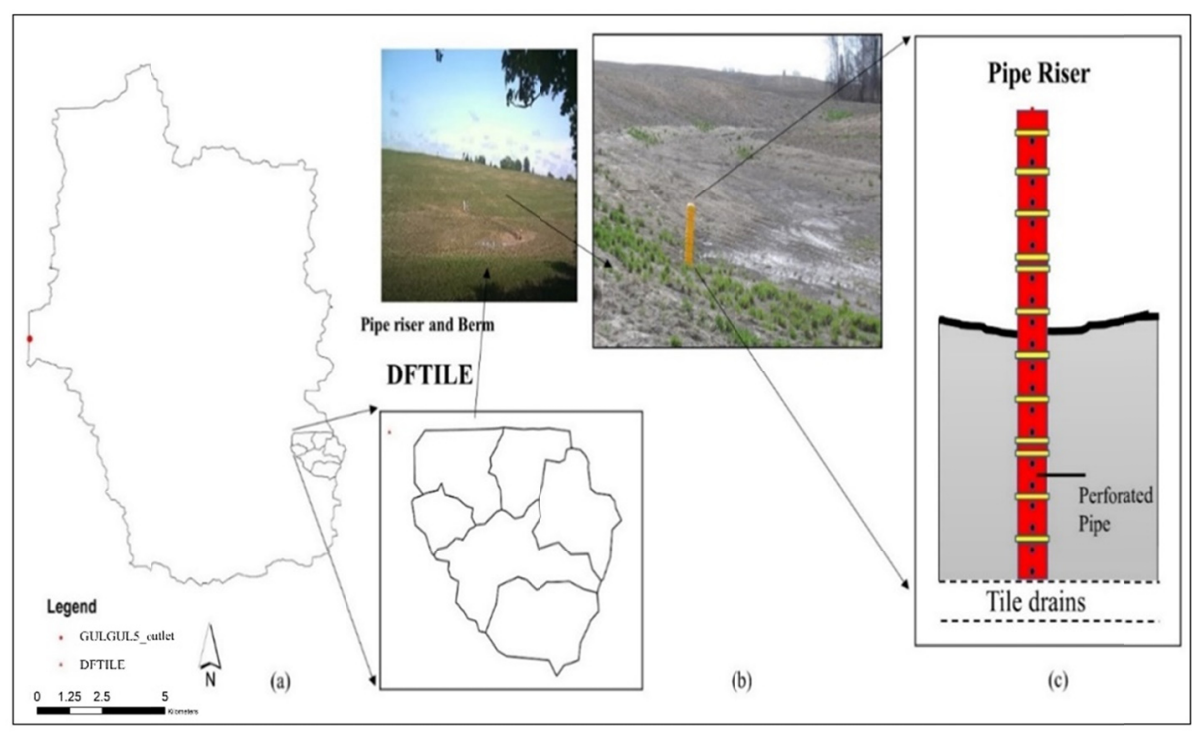

Figure 1. Location of (a) Gully Creek watershed and the DFTILE sub-basin in Ontario, Canada, (b) a typical pipe riser, (c) Pipe riser consisting of a standpipe connected to a subsurface drain

WASCoBs slowly divert surface runoff ponded behind the berm through surface inlets into an underground drainage system, thereby regulating flow and trapping sediments and nutrients $(\mathrm{P}$ and $\mathrm{N})$ within the berm (Fiener et al., 2005; Kovacic et al., 2006; NRCS code 638). Henceforth surface inlets which route water into the drainage system are an exceedingly essential constituent of a WASCoB. Surface inlets are constructed at the point of lowest elevation within the berm and connected directly to the subsurface drainage system (usually tile drains) (Ayars \& Evans, 2015). Based upon their design and function surface inlets are categorized into four types; pipe risers, open inlets, rock inlets, and blind inlets (Li et al., 2017). Amongst them, pipe risers and blind inlets are the most commonly used surface inlets. A pipe riser is a hollow cylindrical tube, with holes encompassing its circumference (Figure 1). Also, perforated pipe risers (also referred to as tile risers) are the most widely adopted type of surface inlets for drainage systems (King et al., 2015; Li et al., 2017; Oolman \& Wilson, 2003). Whereas blind inlet is a permeable area with sections of gravel, sand, and limestone usually constructed at the point of minimum elevation in the berm designed to minimize transport of sediment into the drainage pipe (Gonzalez et al., 2016; Smith \& Livingston, 2013). Since surface inlets are directly coupled with the drainage pipe, they provide an uninterrupted pathway for transportation of runoff and sediment loads (Smith et al., 2008). King et al. (2015) analyzed several studied pertaining to surface inlets and asserted that pollutants could be transported through traditional type of surface inlets. Tomer et al. (2010) studied an Iowa watershed and concluded that discharge from tile risers constituted $15 \%$ of the total flow. Ginting et al. (2000) reported that in a Minnesota watershed, surface inlets transported less than $5 \%$ of annual precipitation into the subsurface drainage system between 1995 and 1998. Authors further reported that dissolved pollutants were transported primarily with snowmelt, and particulate pollutants with severe storm-events.

Although pipe risers are the most commonly used surface inlets for draining huge potholes (Smith \& Livingston, 2013), they significantly accelerate the transport of sediment and other pollutants.

On the contrary, blind inlets, a relatively modern and state-of-art surface inlet having an underground drainage system (NRCS Code 620), have demonstrated a significant reduction in the transport of sediment and nutrient losses (Feyereisen et al., 2015; Smith \& Livingston, 2013; Smith et al., 2015). Hence, it could be a possible alternative to pipe riser for sediment and nutrient. Although potentially more effective in reducing sediment than pipe risers, blind inlets require more maintenance. Sediment trapped needs to be removed frequently culminating in high maintenance costs. Therefore, the lifespan of a blind inlet is uncertain depending upon a plethora of factors such as composition of the inlet (gravel/sand and limestone), type of soil, area of the catchment drained, and farm management practices (Li et al., 2017). Several studies conducted in the past have reported the 
operational life of blind inlets to be greater than 10 years with little to no complication (Feyereisen et al., 2015). However, due to difficulty in monitoring runoff and sediment losses through blind inlets, there is a paucity of published research in this regard. Smith et al. (2015) reported the difference in P concentrations routed through tile risers and blind inlets not to be statistically significant.

Further, Feyereisen et al. (2015) reported that blind inlets produced less TSS compared to open inlets during a three-year investigation in Minnesota. Gonzalez et al. (2016) reported that blind inlets were effective in reducing transport of atrazine, 2,4-D, metolachlor, and glyphosate by $57 \%, 58 \%, 53 \%$, and $11 \%$ respectively. In another study in Ontario, Canada it was revealed that the presence or type of surface inlet (blind inlet or pipe riser) had little impact upon $\mathrm{P}$ and sediment loading along with $\mathrm{N}$ movement through the drainage systems (Ball Coelho et al., 2012a; Ball Coelho et al., 2012b). In another instance in Ontario, Canada McKague, (2017) estimated that blind inlets (constructed with a layer of red sand) were $70 \%$ and $50 \%$ effective respectively, at removing total phosphorus and soluble reactive phosphorus.

Additional research, through sophisticated modeling techniques, is required to quantify the performance of pipe risers and blind inlets in mitigating sediment loads at a watershed scale. Further unlike field experimentation, computer models, are both labor and cost-effective (Golmohammadi et al., 2016). Nonetheless, due to the complexity in simulating flow and sediment transport through surface inlets, no study has investigated modeling flow and sediment transport through blind inlets and pipe risers at a watershed level in Ontario, Canada. Further, hydrologic conditions are an essential aspect to be examined when selecting an appropriate model. Borah et al. (2007) concluded that event-based models perform better in simulating stream flows, constituted by severe storm events. Consequently, since the transport of sediments along with surface runoff is essentially influenced by storm intensity, an event-based modeling approach is more appropriate for modeling pipe risers and blind inlets. AGNPS is one such event-based model, potent in simulating the hydrology of a watershed, routing flow and sediment between cells to the watershed outlet (Cho et al., 2008; Liu et al., 2008; Miklanek et al., 2004; Mohammed et al., 2004; Parajuli et al., 2007; Sebti \& Rudra 2010). However, AGNPS is an event-based model with no groundwater or subsurface module. Therefore, to overcome these limitations a toolbox (CoBAGNPS) was developed which could simulate the movement of flow and sediment both through pipe risers and blind inlets. A sediment module is incorporated in the toolbox to simulate the movement of sediment through pipe risers. Further, the toolbox utilizes the results from AGNPS and integrates it with HYDRUS 1-D model (Meng et al., 2014; Shang et al., 2016) to replicate the movement of flow and sediments through blind inlets. The HYDRUS 1-D model (Meng et al., 2014; Shang et al., 2016) which simulates flow through a porous media is used to duplicate the geometry of a blind inlet. Therefore, the objective of this research was to develop and exhibit through a case study the sediment routing module of the toolbox; routing sediment through pipe riser and blind inlets. The following important question and objective associated with the toolbox developed were addressed in this paper:

- Can CoBAGNPS toolbox simulate the sediment reducing efficiency of WASCoBs when direct runoff is routed through a pipe riser and blind inlets?

- Compare the sediment removal efficiency of pipe risers and blind inlets procured from the toolbox?

\section{Method}

\subsection{Study Area}

Gully Creek watershed located in Ontario, Canada along with one of its sub-basins, the DFTILE sub-basin (having WASCoBs) were selected for this study (Figure 1). This watershed drains into Lake Huron. The watershed encompasses an area of 2611.52 acres with elevation ranging from $281 \mathrm{~m}$ to $217 \mathrm{~m}$ at its outlet. The DFTILE sub-basin comprises of six WASCoBs which drains to the DFTILE outlet through a network of tile drains (Figure 1). Precipitation occurs mostly as rainfall between April and October (nearly $60 \%$ ), while remaining occurs as snow during the winter months. Average annual precipitation occurring in the region is approximately 1,055 mm (monitored between 2001-2011) (Golmohammadi et al., 2017). Detailed description regarding the geographical extent for each soil type in the watershed is provided in Table 1. Further, the landuse distribution of the watershed is presented in Figure 2. Nearly $70 \%$ of the watershed is agricultural land dominated by corn, soybean and winter wheat. Remaining portion of the watershed is mostly under natural vegetation, including trees, shrubs, and grasses. 


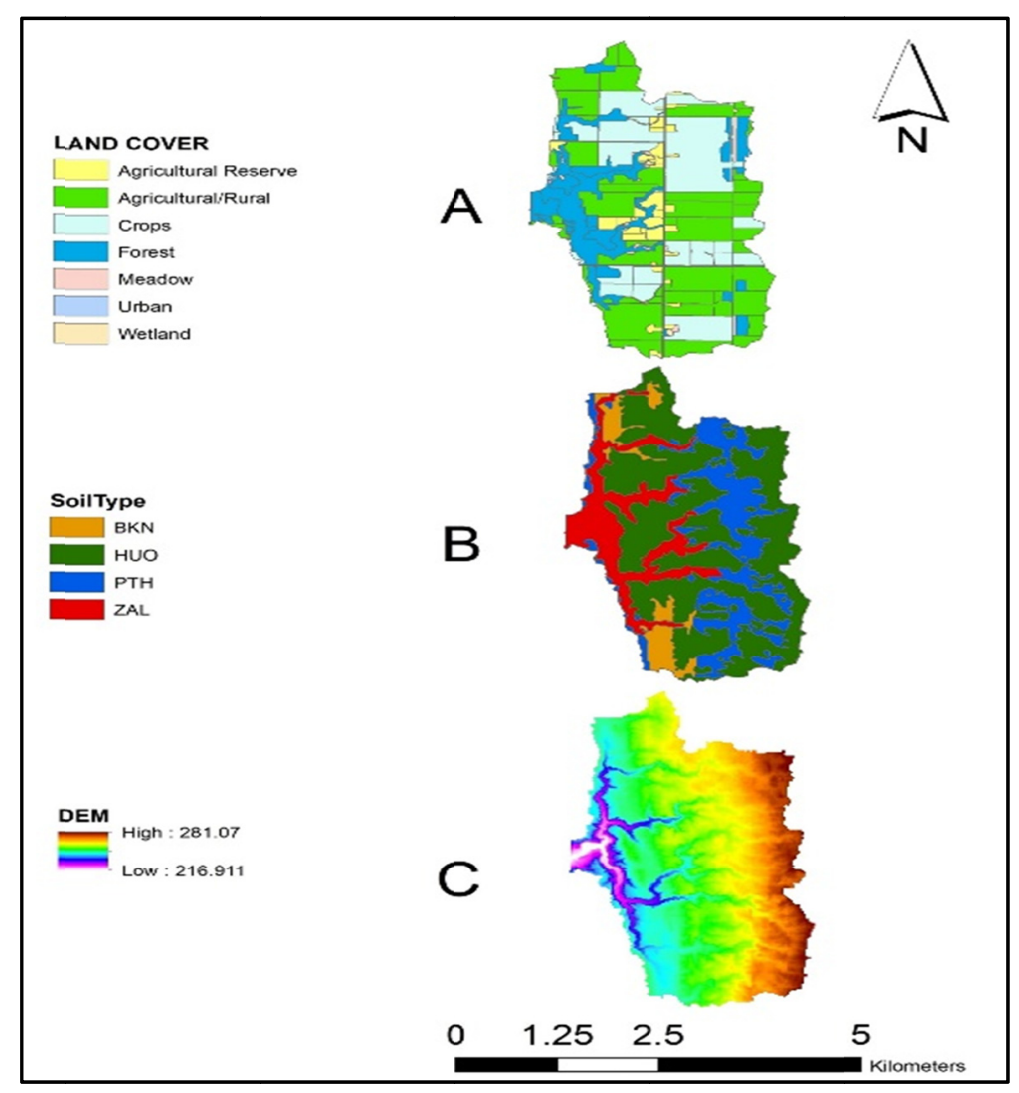

Figure 2. (A) Landuse, (B) Soil, and (C) Digital Elevation model of the Gully creek watershed

Table 1. Name and extent of each soil type in the Gully Creek watershed

\begin{tabular}{llll}
\hline Soil code & Soil type & Area (ha) & Area (\%) \\
ZAL & Bottom Land & 84.57 & 8.08 \\
PTH & Perth Clay Loam & 101.06 & 9.66 \\
HUO & Huron Clay Loam & 797.11 & 76.21 \\
BKN & Brookston Clay Loam & 63.26 & 6.05 \\
\hline
\end{tabular}

Source: OMAFRA, Ontario Ministry of Natural Resources (OMNR), and Ausable Bayfield Conservation Authority (ABCA).

\subsection{CoBAGNPS Development}

CoBAGNPS is written in C\# (www.learncs.org) which is a state-of-art high-level programming language. The design of CoBAGNPS is divided into two parts: (1) CoBAGNPS flow, which consists of the code for routing the flow computed at the outlet cell of the sub-basin cell (representing the WASCoB or berm) procured from the AGNPS model through a combination of pipe risers and drainage pipes and (2) CoBAGNPS sediments, which contains code for routing sediment procured at the outlet cell of the sub-basin through pipe riser and blind inlet. CoBAGNPS can be installed as a stand-alone application. The conceptual architecture of the toolbox is depicted in Figure 3. 


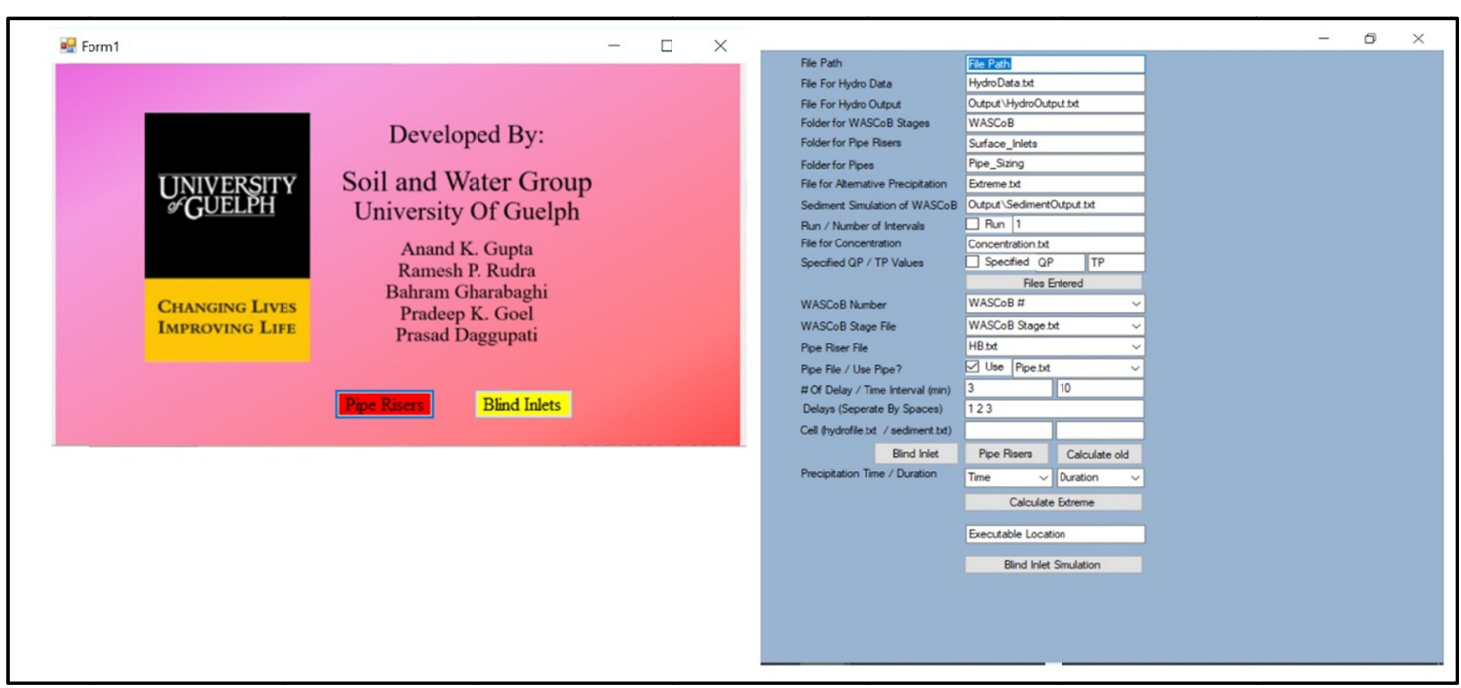

Figure 3. Main interface of the CoBAGNPS Toolbox

\subsubsection{Conceptual Design: Routing of Sediment: Pipe Risers}

WASCoBs are constructed along the pathway of concentrated flow-paths like ephemeral and classical gullies within a watershed (Liu, 2013). Also, water flowing through the berm of the WASCoB branches from the drainage area above it. Therefore, a detailed LiDAR DEM data was utilized to procure a stage-volume (storage) relationships for the ponding area behind each berm in the DFTILE sub-basin (Figure 4). AGNPS model is used to estimate runoff volume and SL generated behind each berm.

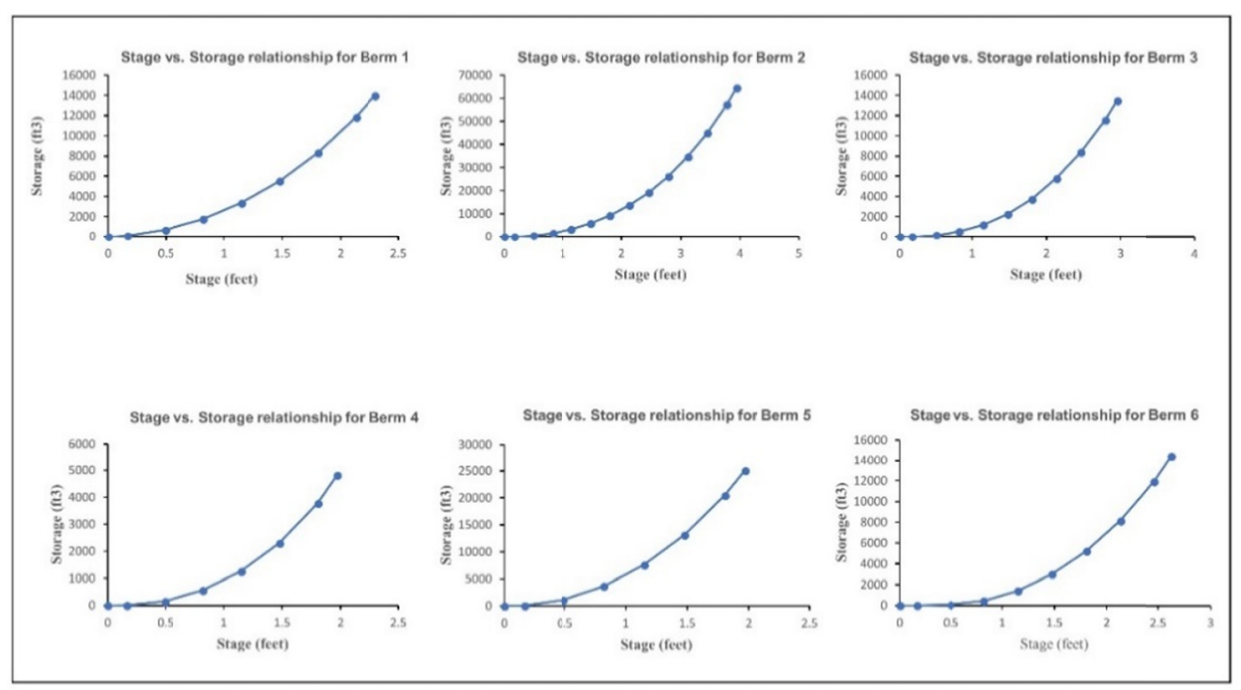

Figure 4. Stage-Storage relationship for all six berms

Further; the stage-storage relationship combined with the stage-discharge relationship for pipe risers (Wilson, 2016) is utilized to determine the discharge from the WASCoB into the drainage pipe. To route sediment amassed behind the berm through the pipe riser, a plug-in sediment routing module was programmed in the toolbox. This conceptualization forms the basis of the sediment module for pipe risers and consists of the following main steps:

- The AGNPS cell delineation was performed such that the drainage area of each WASCoB is represented as a sub-basin and the surface inlet location is represented as the outlet of that sub-basin.

- $\quad$ AGNPS model simulates flow and SL generated at the outlet cell of a WASCoB. 
- Further, the AGNPS model provides the SL for the outlet cell of the WASCoB subdivided into five classes:

- Large Aggregates

- Small Aggregates

- Sand

- Silt

- clay

- Total

- The flow and sediment load thus generated is routed through a pipe riser into the drainage pipe.

- "Plug-flow" method (Wilson \& Barfield 1984) is used to route SL through the pipe riser into the tile drain.

\subsubsection{Conceptual Design: Routing of Sediment-Blind Inlets}

In order to estimate the performance of blind inlets at a watershed scale in removing SL, this study concentrated upon coupling a model which could replicate blind inlets with a watershed scale model. AGNPS model (Young et al., 1989) was used to simulate runoff and SL generated for the drainage area of the WASCoB, while HYDRUS 1-D (Šimůnek et al., 1998) was selected to replicate the blind inlets. Further, a blind inlet (4.25 $\mathrm{m} \times 4.25 \mathrm{~m} \times 1 \mathrm{~m}$ ) located at the lowest elevation point of the WASCoB sub-basin is considered for this modeling exercise. Top $50 \mathrm{~cm}$ of the excavation constitutes of coarse-textured soil; typically sand to aid infiltration. A Geotextile fabric is placed below the soil layer. Further, coarse limestone/gravel is placed below the fabric up to a depth of $50 \mathrm{~cm}$ (Figure 5).

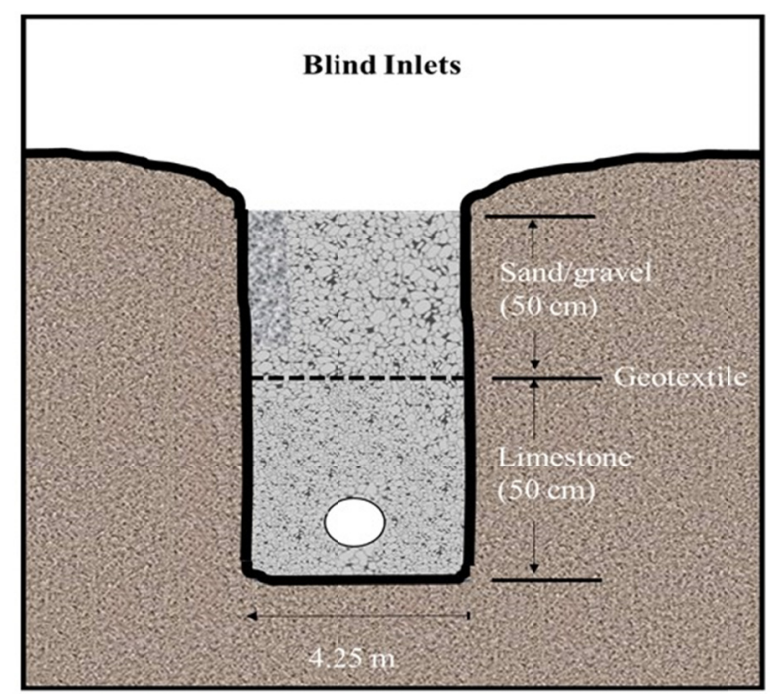

Figure 5. Schematic diagram of a blind inlet.

The purpose of geotextile fabric placed between limestone gravel and sand is to prevent sedimentation within the limestone layer. Further, it reduces the hydraulic efficiency of the layer, thereby preventing drainage. Detailed description of the blind inlet simulated in this study (for scenario analysis) is presented in Smith \& Livingston, (2013). HYDRUS 1-D is used to model infiltration of water ponded behind the berm (computed from AGNPS) through the sand and the limestone layer of the blind inlet. However, HYDRUS 1-D does not simulate the movement of sediment within porous media. To overcome this limitation, an equation (Equation 1) has been proposed to route sediment ponded behind the berm through the sand and the limestone layer of the blind inlet (Neitsch et al., 2002). 


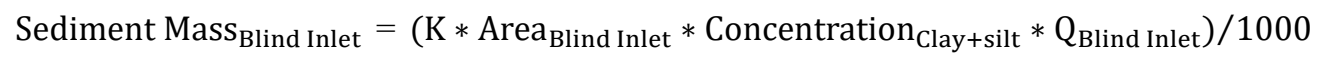

K: Geotextile Filtering coefficient

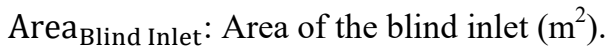

Concentration $_{\text {Clay+Silt }}$ : Concentration of clay and silt in the sediment $\left(\mathrm{kg} / \mathrm{m}^{3}\right)$

$\mathrm{Q}_{\text {Blind Inlet: }}$ Flow of water through the Blind Inlet into the tile drain.

This conceptualization forms the basis of the blind inlet module in the toolbox and consists of the following main steps:

- Cell delineation was executed such that the drainage area for each WASCoB is represented as a sub-basin and the blind inlet location as the outlet of that sub-basin.

- $\quad$ Thereafter, the total quantity of runoff and SL generated behind the berm for each event is computed using the AGNPS model (The AGNPS model is executed within the toolbox).

Further, the hydrology data (flow and sediment) for the outlet cell of each WASCoB sub-basin is procured from the output file of the AGNPS model. The geometry of the blind inlet is modeled by the HYDRUS 1-D model. Finally, the movement of water and sediment through the blind inlet is simulated using the HYDRUS 1-D model and equation 1 programmed in the blind inlet module of the toolbox.

\subsection{AGNPS Model}

AGNPS model (Young et al., 1989) is used to simulate the Gully Creek, Ontario, Canada watershed in this study. AGNPS is a physically-based, event simulation, watershed model. The entire watershed is divided into discrete square cells. The hydrology component of the model computes runoff volume for each cell, using the curve number approach (McCuen, 1982), and peak flow using an empirical equation (Knisel, 1980). Further, the erosion component of the model computes sediment load for each cell using the Bagnold stream power equation (Bagnold, 1966). Comprehensive information pertaining to the model can be procured from the AGNPS manual (Young et al. 1989; http://www.waterbase.org/docs/MWAGNPS\%20Setup.pdf).

\subsection{HYDRUS 1-D Model}

In this study, the HYDRUS-1D code (Šimůnek et al., 1998) is used to simulate 1-D movement of water through a blind inlet. The van Genuchten-Mualem constitutive relationships (described below) are used to simulate the movement of water using equations described in this section.

$$
\begin{gathered}
\theta(\mathrm{h})= \begin{cases}\theta_{r}+\frac{\theta_{s}-\theta_{r}}{\left[1+|\alpha h|^{n}\right]^{m}}, & h<0 \\
\theta_{s}, & h \geq 0\end{cases} \\
\mathrm{k}(\mathrm{h})= \begin{cases}K_{s} S_{e}^{l}\left[1-\left(1-S_{e}^{1 / m}\right)\right]^{2}, & h<0 \\
K_{S}, & h \geq 0\end{cases}
\end{gathered}
$$

where

Where

$$
\mathrm{S}_{\mathrm{e}}=\left(\theta-\theta_{r}\right) /\left(\theta_{s}-\theta_{r}\right), \mathrm{m}=1-1 / \mathrm{n}
$$

$\mathrm{h}=$ soil water pressure head $(\mathrm{cm})$

$\mathrm{k}=$ Hydraulic conductivity $\left(\mathrm{cm} \mathrm{day}^{-1}\right)$

$\theta_{\mathrm{s}}=$ Saturated water content $\left(\mathrm{cm}^{3} \mathrm{~cm}^{-3}\right)$,

$\theta_{\mathrm{r}}=$ Residual water content $\left(\mathrm{cm}^{3} \mathrm{~cm}^{-3}\right)$,

$K_{S}=$ Saturated hydraulic conductivity $\left(\mathrm{cm} \mathrm{day}^{-1}\right)$ and

$\alpha\left(\mathrm{cm}^{-1}\right), \mathrm{n}$ and $\mathrm{l}(=0.5)$ are the shape parameters.

\subsection{Input Data}

DEM (5-m resolution), soil, land use, precipitation data, and stream network is the input data required to model the watershed with the AGNPS model. The required dataset is procured from several sources such as Ontario 
Ministry of Agriculture, Food, and Rural Affairs (OMAFRA), Ontario Ministry of Natural Resources (OMNR), and the Ausable Bayfield Conservation Authority (ABCA).

\subsection{Base Flow Separation}

AGNPS being an event-based model computes only surface runoff. Henceforth; baseflow was separated from streamflow at the outlet of the Gully Creek watershed (GULGUL 5). Surface runoff and base flow compound into streamflow. The former's contribution to streamflow is brisk, on the contrary, base flow's contribution to streamflow is slow (Kalin \& Hantush, 2006). The WHAT program (https://engineering.purdue.edu/mapserve/WHAT/) was used to separate base flow from observed flow (Srivastava et al., 2010; Gupta et al., 2018) based upon signal analysis and processing (Eckhardt \& Arnold, 2001; Kyoung et al., 2005; Lyne \& Hollick, 1979).

\subsection{Sediment Load Estimation}

Observed SL was available for only a few grab samples. Henceforth; sediment loads for these grab samples need to be extrapolated to obtain observed sediment load for each event. Thereafter, observed sediment load for each event was compared with AGNPS simulated sediment load for that event. To extrapolate sediment load of the grab samples on an event basis, LOAD ESTimator (LOADEST) a web-based tool (https://engineering.purdue.edu/mapserve/LOADEST/) was engaged (Park et al., 2015; Runkel et al., 2004). The tool estimates monthly SL using observed streamflow, observed sediment concentration data (for grab samples), and regression model coefficients.

\subsection{Model Calibration and Validation}

Similar to most distributed watershed models (Dile et al., 2016), AGNPS also has a few empirical parameters. Certain variables in AGNPS (CN2, K, C, and P), are not fixed physically (Cho et al., 2008; Choi \& Blood, 1999; Liu et al., 2008). Therefore, the model is calibrated and validated against observed data. In this study, calibration was performed separately for peak flow, direct runoff and sediment yield for nine storm events between June 2012 and August 2013. Further, validation was performed using nine storm events between August 2013 and June 2015. Seasonal calibration and validation were also performed for peak flow, direct runoff, and sediment yield. Observed flow data were obtained from the Ausable Bayfield Conservation Authority (ABCA) at the watershed outlet. Calibration process was accomplished by changing AGNPS parameters to match the model-predicted peak flow, direct runoff and sediment yield with its counterpart. The parameters calibrated were the curve number (CN2) manning's n, C, and K, which have considerable influence upon peak flow, surface runoff, and sediment yield. $\mathrm{CN}$ is altered based upon antecedent moisture conditions. Statistical parameters used to evaluate model's performance are elaborated in Table 2.

Table 2. Statistical parameters used to assess the model's performance

\begin{tabular}{ll}
\hline Statistical Parameter & Formula \\
$\mathrm{R}^{2}$ & $\frac{\left[\sum_{i=1}^{N}\left(O_{o b s, i}-\bar{O}_{o b s}\right)\left(O_{s i m, i}-\bar{O}\right)\right]}{\left[\sum_{i=1}^{N}\left(O_{o b s, i}-\bar{O}_{o b s}\right)^{2}\right]^{0.5}\left[\sum_{i=1}^{N}\left(O_{s i m, i}-\bar{O}_{s i m}\right)^{2}\right]^{0.5}}$ \\
& $1.0-\frac{\left[\sum_{i=1}^{N}\left(O_{s i m, i}-O_{o b s, i}\right)^{2}\right]}{\left[\sum_{i=1}^{N}\left(O_{o b s, i}-\bar{O}_{o b s, i}\right)^{2}\right]}$ \\
& Where \\
& $O_{\text {sim }, i}=$ Simulated flows \\
& $O_{o b s, i}=$ Observed flows \\
& $\mathrm{N}=$ Number of observations \\
& $\bar{O}_{o b s}=$ Mean observed flow \\
& $\bar{O}_{s i m}=$ Mean simulated flow \\
\hline
\end{tabular}

\subsection{Routing Sediment: Pipe Riser and Blind Inlet}

For this study, a set of scenario analyses were simulated using the CoBAGNPS toolbox developed. Statistically calibrated and validated AGNPS results were used to compute the sediment reducing efficiency of pipe risers and blind inlets through the toolbox. Furthermore, sediment removal efficiency was evaluated for three different 
types of pipe risers (HB, HBS, and PI). A couple of storm events (18 April 2013 and 1 August 2013) were selected to perform scenario's pertaining to pipe risers. Further, a currently installed drainage pipe of $150 \mathrm{~mm}$ diameter is considered for simulation. Under the first set of scenario analysis, the performance of the different type of pipe risers (HB, HBS, and PI) in routing sediment load from the berm into the tile drains was analyzed for WASCoB 3 for the selected storm events. Additionally, the sediment routing efficiency of the HB pipe risers was investigated for two synthetic design storm events (5 and 10-year, 24-hour) for various diameters of drainage pipes. In another scenario analysis, the impact of blind inlet upon SL routed into the drainage pipe for WASCoB 3 was assessed. Sediment constantly gets trapped within the blind inlet reducing its efficiency and lifespan (Li et al., 2017). Therefore, analysis pertaining to extreme storm events was not investigated for blind inlets. Storm events with moderate intensity (18 April 2013 and 1 August 2013) were used to test the performance of the blind inlet module of the toolbox.

\section{Results}

\subsection{Calibration and Validation of Flow and Sediments at the GULGUL 5 Outlet}

In this study, data for individual seasons were utilized to calibrate and validate the model on a seasonal basis. A calibration method based upon seasonal calibration is proposed for calibration and validation of storm events. Six storm events were considered for spring, summer and fall season. Further, the events were bifurcated into three events for calibration and validation respectively. Model parameters were adjusted for the calibration events for each season. Statistical parameters were however computed for total calibration and validation events respectively, compounded for all the seasons.

\subsubsection{Flow: Seasonal Calibration}

Seasonal calibration was performed for peak flow and direct runoff at the watershed outlet (GULGUL 5 station). Table 3 summarizes the events selected for calibration and validation for fall, spring and summer respectively. Overall the model performed well. For peak flow, $\mathrm{R}^{2}$ and $\mathrm{E}_{\mathrm{NS}}$ values of 0.97 and 0.89 for calibration events and 0.91 and 0.83 for validation events were obtained. Also, $\mathrm{R}^{2}$ and $\mathrm{E}_{\mathrm{NS}}$ values of 0.87 and 0.73 respectively for calibration events and 0.91 and 0.46 for validation events were procured for direct runoff.

Table 3. Events selected for calibration and validation based upon different seasons [surface runoff (OSR, SSR) and peak flow]

\begin{tabular}{|c|c|c|c|c|c|c|c|c|c|}
\hline Season & Date & PCP (mm) & Duration (hours) & $\mathbf{A M C}$ & manning's (n) & $\begin{array}{l}Q_{P e a k}^{\text {Observed }} \\
\mathrm{m}^{3} / \mathrm{s} \\
\end{array}$ & $\begin{array}{l}Q_{P e a k}^{\text {Simulated }} \\
\mathrm{m}^{3} / \mathrm{s}\end{array}$ & $\operatorname{OSR}\left(\mathrm{m}^{3}\right)$ & $\operatorname{SSR}\left(\mathrm{m}^{3}\right)$ \\
\hline & 14-Oct-12 & 18.4 & 20 & II & 0.02 & 0.12 & 0.2 & 6316.47 & 5367.45 \\
\hline \multirow[t]{2}{*}{ Fall (Cal) } & 14-Sep-12 & 17.2 & 7 & II & 0.02 & 0.07 & 0.13 & 791.81 & 2683.73 \\
\hline & 20-Sep-13 & 24.8 & 5 & II & 0.02 & 0.34 & 0.49 & 6010.55 & 5367.45 \\
\hline Average & & & & & & 0.18 & 0.27 & 4372.94 & 4472.88 \\
\hline Spring & 18-Apr-13 & 30.6 & 10 & II & 0.02 & 2.38 & 2.78 & 37471.43 & 37572.18 \\
\hline \multirow[t]{2}{*}{ (Cal) } & 12-Apr-14 & 27.39 & 7 & II & 0.02 & 1.79 & 1.62 & 35127.5 & 26837.27 \\
\hline & 28-Мay-13 & 21 & 5 & II & 0.02 & 0.4 & 0.48 & 10684.92 & 10734.91 \\
\hline Average & & & & & & 1.52 & 1.63 & 27761.28 & 25048.12 \\
\hline \multirow[t]{3}{*}{ Summer (Cal) } & 01-Aug-13 & 59 & 15 & I & 0.04 & 1.29 & 1.92 & 19174.36 & 34888.42 \\
\hline & 16-Jun-13 & 14 & 6 & II & 0.02 & 0.09 & 0.08 & 3500.15 & 2683.73 \\
\hline & 28-Jun-13 & 15.8 & 8 & II & 0.02 & 0.08 & 0.09 & 1817.56 & 2683.73 \\
\hline \multirow[t]{2}{*}{ Average } & & & & & & 0.49 & 0.7 & 8164.03 & 13418.63 \\
\hline & 20-Oct-12 & 15.8 & 15 & II & 0.02 & 0.13 & 0.09 & 5016.29 & 5367.45 \\
\hline \multirow[t]{2}{*}{ Fall (Val) } & 17-Oct-13 & 18 & 12 & II & 0.02 & 0.48 & 0.35 & 16196.08 & 8051.18 \\
\hline & 12-Nov-12 & 16.4 & 9 & II & 0.02 & 0.2 & 0.2 & 6015.05 & 5367.45 \\
\hline Average & & & & & & 0.27 & 0.21 & 9075.81 & 6262.03 \\
\hline Spring & 29-Apr-14 & 22.4 & 9 & II & 0.02 & 0.67 & 0.65 & 20829.96 & 13418.64 \\
\hline \multirow[t]{2}{*}{ (Val) } & 24-Apr-13 & 20.2 & 21 & II & 0.02 & 0.39 & 0.39 & 18715.47 & 8051.18 \\
\hline & 31-Мay-13 & 10.6 & 9 & III & 0.02 & 0.39 & 0.33 & 13303.28 & 8051.18 \\
\hline Average & & & & & & 0.48 & 0.46 & 17616.24 & 9840.33 \\
\hline Summer & 30-Aug-13 & 18 & 3 & II & 0.02 & 0.28 & 0.26 & 3203.23 & 5367.45 \\
\hline \multirow[t]{2}{*}{ (Val) } & 12-Jun-12 & 18.2 & 2 & II & 0.02 & 0.34 & 0.28 & 5605.64 & 5367.45 \\
\hline & 12-Jun-13 & 19 & 3 & II & 0.02 & 0.24 & 0.26 & 6829.35 & 5367.45 \\
\hline \multirow[t]{2}{*}{ Average } & & & & & & 0.29 & 0.27 & 5212.74 & 5367.45 \\
\hline & & Peak Flow & Direct runoff & & & & & & \\
\hline \multirow[t]{2}{*}{ Calibration (Cal) } & $\mathrm{R}^{2}$ & 0.97 & 0.87 & & & & & & \\
\hline & $\mathrm{E}_{\mathrm{NS}}$ & 0.89 & 0.73 & & & & & & \\
\hline \multirow[t]{2}{*}{ Validation (Val) } & $\mathrm{R}^{2}$ & 0.91 & 0.91 & & & & & & \\
\hline & $\mathrm{E}_{\mathrm{NS}}$ & 0.83 & 0.46 & & & & & & \\
\hline
\end{tabular}




\subsubsection{Sediment: Seasonal Calibration}

Table 4 shows the events selected for calibration and validation of SL during fall, spring and summer seasons respectively. As described in the section above, six events are selected for each season, where three events are used for model calibration and three events for model validation. The calibration process was completed by altering parameters within the AGNPS model to match the model-predicted SL with the observed SL. It is a prerequisite to complete calibration and validation for flow before initiating the process for sediment calibration. The parameters varied during calibration are shown in Table 5.

Table 4. Events selected for calibration and validation based upon different seasons [surface runoff (OSR, SSR) and sediment yield (OSL, SSL)]

\begin{tabular}{|c|c|c|c|c|c|c|c|c|c|}
\hline Season & Date & $\begin{array}{l}\text { PCP } \\
(\mathrm{mm}) \\
\end{array}$ & $\begin{array}{l}\text { Duration } \\
\text { (hours) }\end{array}$ & AMC & $\begin{array}{l}\text { manning's } \\
\text { (n) }\end{array}$ & $\begin{array}{l}\text { OSR } \\
\left(\mathbf{m}^{3}\right) \\
\end{array}$ & $\begin{array}{l}\text { SSR } \\
\left(\mathrm{m}^{3}\right) \\
\end{array}$ & $\begin{array}{l}\text { OSL } \\
\text { (tons) }\end{array}$ & $\begin{array}{l}\text { SSL } \\
\text { (tons) }\end{array}$ \\
\hline \multirow{4}{*}{ Fall (Cal) } & 14-Oct-12 & 18.4 & 20 & II & 0.02 & 6316.47 & 5367.45 & 0.74 & 1.05 \\
\hline & 14-Sep-12 & 17.2 & 7 & II & 0.02 & 791.81 & 2683.73 & 0.023 & 1.27 \\
\hline & 20-Sep-13 & 24.8 & 5 & I & 0.02 & 6010.55 & 5367.45 & 0.27 & 1.71 \\
\hline & Average & & & & & 0.27 & 4372.94 & 4472.88 & 0.34 \\
\hline \multirow{4}{*}{$\begin{array}{l}\text { Spring } \\
\text { (Cal) }\end{array}$} & 18-Apr-13 & 30.6 & 10 & II & 0.02 & 37471.4 & 37572.2 & 19.49 & 16.8 \\
\hline & 12-Apr-14 & 27.39 & 7 & II & 0.02 & 35127.5 & 26837.3 & 12.79 & 15.11 \\
\hline & 28-May-13 & 21 & 5 & II & 0.02 & 10684.9 & 10734.9 & 0.65 & 9.1 \\
\hline & Average & & & & & 1.63 & 27761.3 & 25048.1 & 10.98 \\
\hline \multirow{5}{*}{$\begin{array}{l}\text { Summer } \\
\text { (Cal) }\end{array}$} & 01-Aug-13 & 59 & 15 & I & 0.04 & 19174.4 & 34888.4 & 19.49 & 22.89 \\
\hline & 16-Jun-13 & 14 & 6 & II & 0.02 & 3500.15 & 2683.73 & 0.2983 & 1.25 \\
\hline & 28-Jun-13 & 15.8 & 8 & II & 0.02 & 1817.56 & 2683.73 & 0.32 & 1.41 \\
\hline & Average & & & & & 0.7 & 8164.03 & 13418.6 & 6.7 \\
\hline & 20-Oct-12 & 15.8 & 15 & II & 0.02 & 5016.29 & 5367.45 & 1.2897 & 1.22 \\
\hline \multirow[t]{3}{*}{ Fall (Val) } & 17-Oct-13 & 18 & 12 & II & 0.02 & 16196.1 & 8051.18 & & \\
\hline & 12-Nov-12 & 16.4 & 9 & II & 0.02 & 6015.05 & 5367.45 & 0.91 & 1.67 \\
\hline & Average & & & & & 0.21 & 9075.81 & 6262.03 & 1.1 \\
\hline \multirow{4}{*}{$\begin{array}{l}\text { Spring } \\
\text { (Val) }\end{array}$} & 29-Apr-14 & 22.4 & 9 & II & 0.02 & 20830 & 13418.6 & 12.42 & 9.31 \\
\hline & 24-Apr-13 & 20.2 & 21 & II & 0.02 & 18715.5 & 8051.18 & 20.85 & 8.36 \\
\hline & 31-May-13 & 10.6 & 9 & III & 0.02 & 13303.3 & 8051.18 & 2.584 & 2.61 \\
\hline & Average & & & & & 0.46 & 17616.2 & 9840.33 & 11.95 \\
\hline Summer & 30-Aug-13 & 18 & 3 & II & 0.02 & 3203.23 & 5367.45 & 4.945 & 3.07 \\
\hline \multirow[t]{8}{*}{ (Val) } & 12-Jun-12 & 18.2 & 2 & II & 0.02 & 5605.64 & 5367.45 & 0.1327 & 0.82 \\
\hline & 12-Jun-13 & 19 & 3 & II & 0.02 & 6829.35 & 5367.45 & 0.533 & 0.76 \\
\hline & Average & & & & & 0.27 & 5212.74 & 5367.45 & 1.87 \\
\hline & \multicolumn{9}{|c|}{ Statistical Parameter } \\
\hline & & & & Calibration & $\mathrm{R}^{2}$ & 0.94 & & & \\
\hline & & & & (Cal) & $\mathrm{E}_{\mathrm{NS}}$ & 0.83 & & & \\
\hline & & & & Validation & $\mathrm{R}^{2}$ & 0.92 & & & \\
\hline & & & & (Val) & $\mathrm{E}_{\mathrm{NS}}$ & 0.56 & & & \\
\hline
\end{tabular}

Table 5. Calibrated AGNPS parameters

\begin{tabular}{ll}
\hline Parameters adjusted during model calibration & Description \\
$\mathrm{CN}$ & SCS curve number \\
$\mathrm{n}$ & Manning's n \\
$\mathrm{K}$ & Soil erodibility factor \\
$\mathrm{C}$ & Crop practice factor \\
$\mathrm{P}$ & Crop management factor \\
\hline
\end{tabular}

These parameters were manually manipulated for each grid and its channel until peak flow, direct runoff and SL simulated at the outlet grid of the AGNPS model closely matches the observed value for parameters simulated. 
Adjustment of the SCS curve number (CN2), has been found necessary for calibration and validation for surface runoff and peak flow in many AGNPS studies (Cho et al., 2008; Liu et al., 2008; Parajuli et al., 2007). Likewise, alteration of K, C, and P factors have been found necessary for calibration and validation for SL generated (Choi \& Blood, 1999). The logic behind altering $\mathrm{CN}, \mathrm{n}, \mathrm{K}, \mathrm{C}$, and $\mathrm{P}$ for each grid is that once a close agreement is reached between observed and model-simulated values at the watershed outlet, the adjusted values for these model parameters would be realistic and match the real-world parameters for each grid within the watershed. Henceforth, the model parameters values within the DFTILE sub-basin would represent the real-world dynamics. Therefore, it could be assumed that the hydrologic parameters applied at the outlet cell for each WASCoB would match the real-world hydrologic parameters. Hence, flow and SL procured after routing water ponded behind the berms through the blind inlet would be realistic.

Instantaneous SL concentrations were available at the watershed outlet (Figure 1) between 2012 and 2014. This data was transformed into monthly SL using LOADEST as described in the above section. Estimated monthly SL was further converted to event-based loads depending upon the month of the event. These events were used for calibration. Also, the model was validated against observed SL in the next phase. Three events each for summer, spring, and fall season were used for SL calibration and validation respectively (see Table 4). The observed average SL of 6.7 tons was slightly lower than the simulated load of 8.52 tons over the calibration period for the summer season. Comparable results were observed for calibration events during the spring and fall period where again the model overestimated the observed SL (Figure 6).
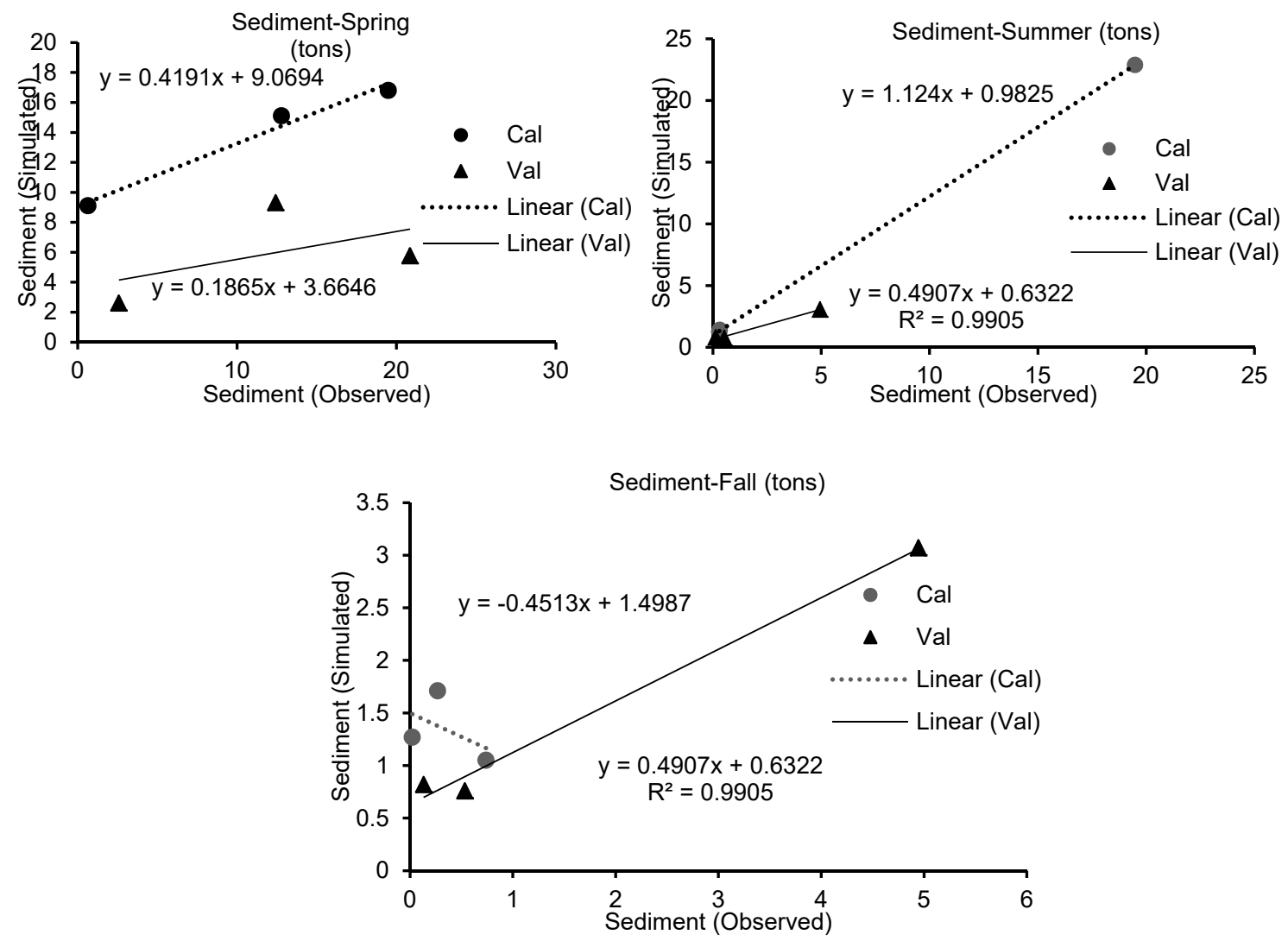

Figure 6. Observed and simulated SL at the GULGUL 5 outlet (a) summer season, (b) fall season, and (c) spring season

Table 4 shows that, except for 14 September 2012 and 28 May 2013 events, the model was able to capture SL for most of the calibration events (2012-2014). The AGNPS model substantially overestimated SL for these two events. The overestimation in these 2 events may be due to the lack of observed grab samples during this period. Hence, the observed SL for these events could have been substantially under-predicted. Except for a few events, the model was able to simulate SL accurately during the calibration period. 
Performance statistics $\left[\mathrm{R}^{2}=0.94\right.$ and $\mathrm{E}_{\mathrm{NS}}=0.83$ (for all the calibration events combined) ] further confirms that simulated SL adequately matched observed SL at the watershed outlet for the calibration events (see Table 4).

During the validation period, pertinent results were procured. The measured average SL of 1.87 tons was slightly higher than the simulated load of 1.55 tons for the validation events during the summer season. Comparable results were observed for the spring and fall period where again the model underestimated observed SL (Figure 6). Overall, the model underestimated the SL for the validation events (see Table 4). Further, except for the 17 October 2013 event where the model substantially underestimated the SL, the model was successful in capturing SL for most of the events during the validation period (2012-2014). The underestimation in this event is due to some very large storms, which might not have been captured accurately by the weather station. The estimated rainfall recorded was $18 \mathrm{~mm}$ during the event (which might have been measured inaccurately). To obtain a better model performance during the validation period, SL for this event was removed. Thereafter, appropriate model statistics $\left(R^{2}=0.92\right.$ and $\left.E_{N S}=0.56\right)$ were obtained indicated that AGNPS successfully simulated SL for the watershed (see Table 4).

\subsection{Routing Sediment: Pipe Riser}

\subsubsection{Scenario 1: Sediment Routed Through WASCoB 3 Using Different Type of Pipe Risers}

Under this investigation, the impact of the different type of pipe risers (HB, HBI, PI) upon the sediment routed into the drainage pipe for WASCoB 3 is analyzed. Sediment removal efficiency for the HB pipe riser is $94.31 \%$ for 18 April 2013 storm event, however, for 1 August 2013 storm event an increased removal efficiency of $96.14 \%$ was procured (see Table 6). Further upon routing flow through the HBS pipe riser, the sediment removal efficiency increased marginally to $94.87 \%$ for the 18 April 2013 storm event and $96.42 \%$ for 1 August 2013 storm event (see Table 6). Adopting the HBS pipe riser, resulted in an increase in drainage time for the storm, thereby allowing more time for sediment to settle within the berm thereby increasing the sediment removal efficiency (Figure 7 and 8). Also, another scenario where water is routed through a PI pipe riser is also considered. Under this investigation, sediment removal efficiencies of $95.23 \%$ and $97.21 \%$ were obtained for 18 April 2013 and 1 August 2013 storm event respectively. Henceforth results reveal that adopting a PI pipe riser is more efficient and practical in optimizing sediment removal efficiency.

Table 6. Sediment removal efficiency for various pipe risers

\begin{tabular}{lllll}
\hline Storm event & Pipe Riser & Inflow load $(\mathrm{kg})$ & Outflow load & Sediment Removal Efficiency \\
18-Apr-13 & HB & 160 & 9.1 & 94.31 \\
& HBS & 160 & 8.21 & 94.87 \\
& PI & 160 & 7.64 & 95.23 \\
01-Aug-13 & HB & 150 & 5.79 & 96.14 \\
& HBS & 150 & 5.37 & 96.42 \\
& PI & 150 & 4.19 & 97.21 \\
\hline
\end{tabular}
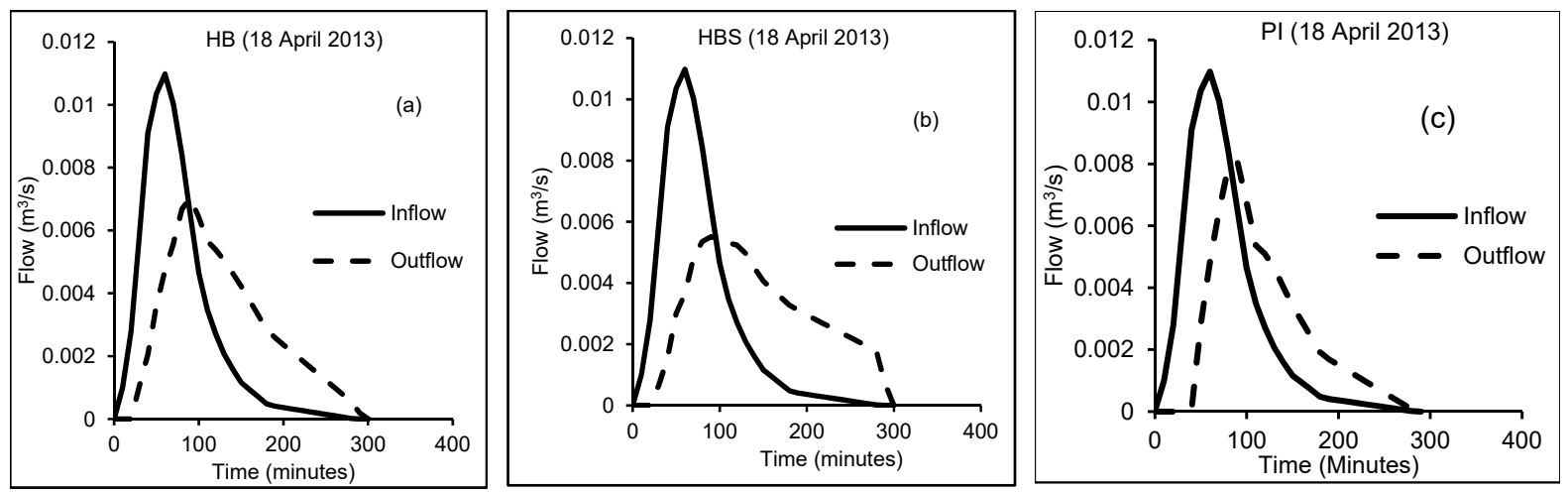

Figure 7. Flow simulated at the outlet for WASCoB 3 for different type of pipe risers (a) 18 April 2013 HB pipe riser, (b) 18 April 2013 HBS pipe riser, (c) 18 April 2013 PI pipe riser 

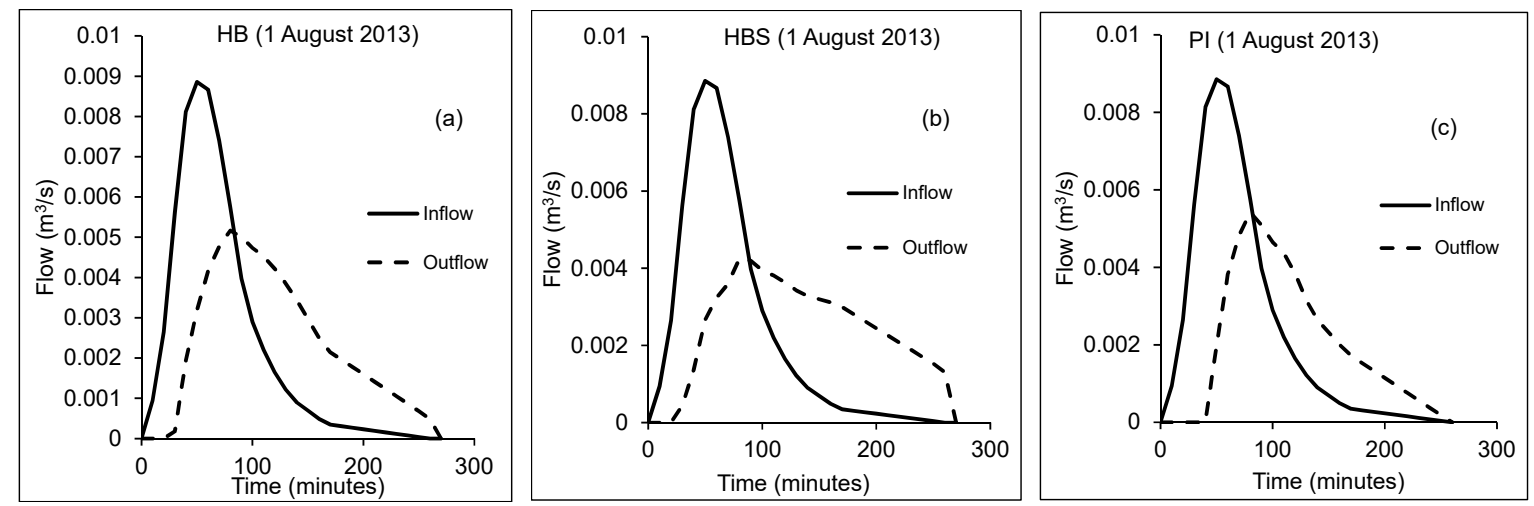

Figure 8. Flow simulated at the outlet for WASCoB 3 for different type of pipe risers (a) 1 August 2013 HB pipe riser, (b) 1 August 2013 HBS pipe riser, (c) 1 August PI pipe riser

\subsubsection{Scenario 2: 5-Year 24-Hour Design Storm}

Drainage pipes with a diameter of $150 \mathrm{~mm}$ (present case), $200 \mathrm{~mm}$ and $375 \mathrm{~mm}$ were selected to route sediment through an HB pipe riser for a 5-year 24-hour design storm. Sediment removal efficiencies of $76.06 \%, 63.07 \%$, and $46.15 \%$ were observed for $150 \mathrm{~mm}, 200 \mathrm{~mm}$ and $375 \mathrm{~mm}$ drainage pipes respectively. A 5-year 24-hour design storm generates a much higher quantity of SL of $260 \mathrm{~kg}$. Also, the sediment removal efficiency of this design storm is lower than 18-Apr-13 and 01-Aug-13 storm events. This is expected because a heavy storm event (for example a 5-year 24-hour or 10-year 24-hour design storm) would generate a large amount of fine sediment particles (clay, silt, and sand). These finer particles are difficult to settle compared to large sediment particles like small aggregates and large aggregates and hence it is expected to have lower sediment removal efficiency as compared to real design storms. Furthermore, a discrepancy in the sediment removal efficiency is primarily due to the time for which water is ponded behind the berm. The $150-\mathrm{mm}$ drainage pipe routes water, flowing at its optimum capacity $\left(0.01099 \mathrm{~m}^{3} / \mathrm{s}\right)$ for 10 hours and 10 minutes approximately. Henceforth, there is sufficient time for fine sediment particles like silt and clay to settle within the berm. When the diameter of the outlet pipe is increased to $200 \mathrm{~mm}$ and $375 \mathrm{~mm}$ a substantial change in the flow pattern is observed in the routing efficiency of the WASCoB (Figure 9). The $200 \mathrm{~mm}$ drainage pipe is more efficient in draining the water ponded behind the berm. The pipe flows at its optimum capacity only for approximately three hours and forty-five minutes respectively; thereby significantly reducing the ponding time. However, with an increase in the draining efficiency, finer sediment particles (silt, clay etc.) have less time to settle within the berm; thereby significantly reducing the sediment removal efficiency of the pipe riser (see Table 7). Another scenario of employing a 375-mm drainage pipe was also considered. Graphical comparison between the three pipes (Figure 9) reveals that the $375-\mathrm{mm}$ drainage pipe is potent in draining water at a much rapid rate. Also, it is never flowing at its optimum capacity. Henceforth; since its ponding time is the least amongst the three scenarios of drainage pipe considered, sediment particles get minimum time to settle within the berm resulting in the least sediment removal efficiency.
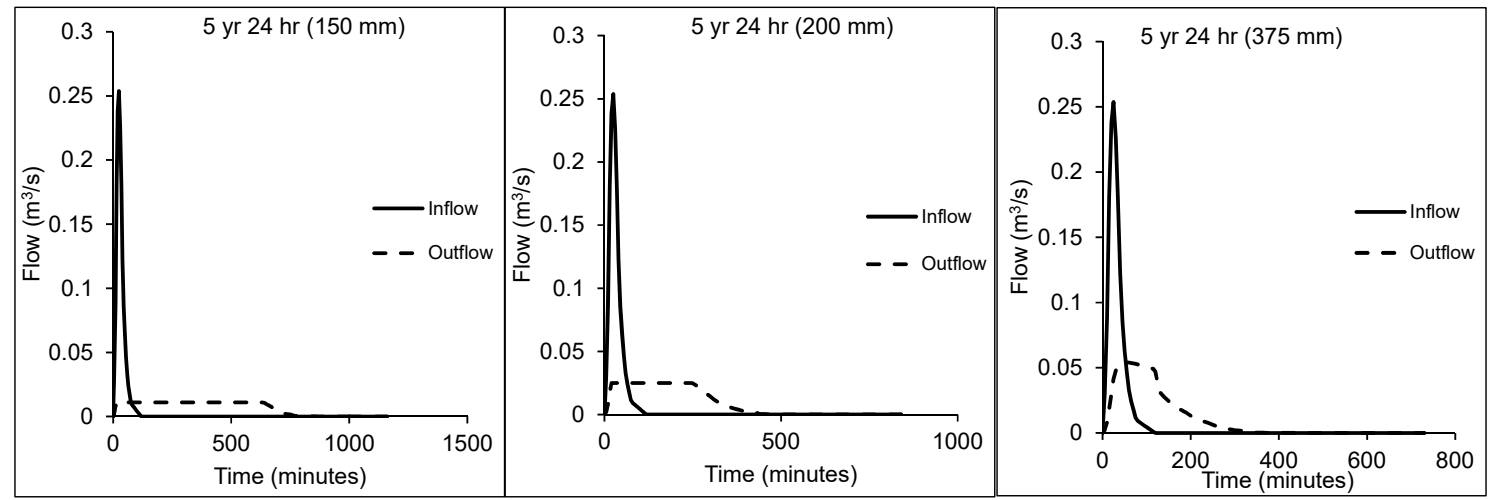

Figure 9. Flow simulated through WASCoB 3 for 5-year 24-hour storm event: routed through a (a) $150 \mathrm{~mm}$ (b) $200 \mathrm{~mm}$ and (c) $375 \mathrm{~mm}$ drainage pipes 


\subsubsection{Scenario 4: 10-Year 24-Hour Design Storm}

A scenario for routing a 10-year 24-hour design storm through a drainage pipe of $150 \mathrm{~mm}, 200 \mathrm{~mm}$ and $375 \mathrm{~mm}$ diameter was also considered in this study. This storm produces a SL of $360 \mathrm{~kg}$ for WASCoB 3 drainage area. Tile drains of various diameter have sediment removal efficiency between 49.96 and $76.48 \%$ (see Table 7). A $150 \mathrm{~mm}$ drainage pipe removes $275.36 \mathrm{~kg}$ of SL (see Table 7) and therefore, has the maximum sediment removal efficiency. This is expected because a $150 \mathrm{~mm}$ diameter drainage pipe takes the maximum amount of time to drain stormwater ponded (Figure 10). Therefore, sediment particles take a longer time to settle compared to other drainage pipes (200 and $375 \mathrm{~mm}$ ).

Table 7. Sediment removal efficiency for various design storms

\begin{tabular}{llllll}
\hline Extreme Event & Pipe Riser & Tile Drain & Inflow Load (Kg) & Outflow Load (kg) & Sediment Removal Efficiency \\
\hline 5-year-24-hour & HB & $150 \mathrm{~mm}$ & 260 & 62.22 & 76.07 \\
& & $200 \mathrm{~mm}$ & 260 & 96 & 63.08 \\
& & $375 \mathrm{~mm}$ & 260 & 140 & 46.15 \\
10-year-24-hour & HB & $150 \mathrm{~mm}$ & 360 & 84.64 & 76.49 \\
& & $200 \mathrm{~mm}$ & 360 & 125.47 & 65.15 \\
& & $375 \mathrm{~mm}$ & 360 & 180.11 & 49.97 \\
\hline
\end{tabular}
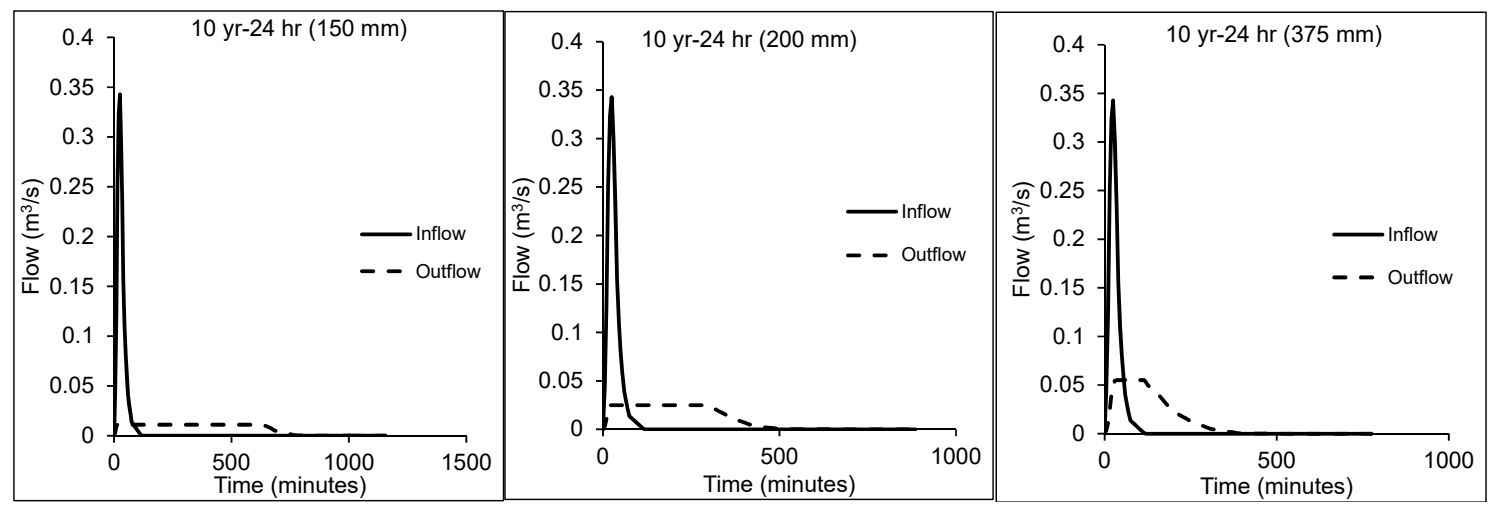

Figure 10. Flow simulated through WASCoB 3 for 10-year 24-hour storm event: routed through a (a) $150 \mathrm{~mm}$ (b) $200 \mathrm{~mm}$ and (c) $375 \mathrm{~mm}$ drainage pipes

\subsubsection{Routing Sediment: Blind Inlets}

In another scenario analysis, the sediment removal efficiency of blind inlets was investigated for 18 April 2013 and 1 August 2013 storm events. WASCoB 3 was again used for simulation. Sediment removal efficiency for the HB pipe riser was $81.25 \%$ for 18 April 2013 storm event; however, for 1 August 2013 storm event the sediment removal efficiency increased marginally to $86.67 \%$ (see Table 8 ). Sediment routing module for blind inlets programmed in the toolbox has a simple empirical approach (Eq 1) where it assumes heavy particles like sand, small aggregates, and large aggregates are settled within the berm. Only fine particles like silt and clay, which are difficult to settle and require a long time to settle would be in dissolved form and hence cannot be removed through blind inlet. Since the two storm events considered for analysis (18 April 2013 and 1 August 2013) generate almost the same quantity of sediment load their sediment removal efficiencies are also similar. 
Table 8. Sediment removal efficiency for blind inlets

\begin{tabular}{ccc}
\hline Storm event & $2013-04-18$ & $2013-08-01$ \\
Sand $(\mathrm{kg})$ & 10.00 & 10.00 \\
Silt $(\mathrm{kg})$ & 10.00 & 10.00 \\
Clay $(\mathrm{kg})$ & 20.00 & 10.00 \\
Small Aggregates $(\mathrm{kg})$ & 80.00 & 80.00 \\
Large Aggregates $(\mathrm{kg})$ & 40.00 & 40.00 \\
Total Inflow load into the blind inlet $(\mathrm{kg})$ & 160.00 & 150.00 \\
Total Outflow load into the tile drain $(\mathrm{kg})$ & 30.00 & 20.00 \\
Removal Efficiency & 81.25 & 86.67 \\
\hline
\end{tabular}

\section{Conclusion}

Modeling sediment through surface inlets (viz. pipe risers and blind inlets), through hydrological models has not yet been documented in Canada. We developed a user-driven stand-alone graphical user interface toolbox, called CoBAGNPS, to evaluate the sediment removal efficiency of surface inlets, which are an exceedingly important constituent of a WASCoB. This paper provides details of the toolbox tested using a case study. The AGNPS and HYDRUS 1-D model are integrated with the interface of the toolbox for routing the SL through blind inlets. Once the AGNPS model is successfully developed, calibrated, and validated for the watershed, the toolbox was executed. Three different pipe risers (HB, HBS, and PI) and various diameter of tile drains were used to simulate the sediment removal efficiency of the toolbox for 12 April 2014 and 18 April 2013 storm events. Also, the sediment removal efficiency for two extreme events (5-year and 10-year with a 24-hour) for one WASCoB was evaluated. It must be stressed that the toolbox simply utilizes the outlet results of the AGNPS model and feeds it as an input file into the HYDRUS 1-D model for routing sediment through blind inlets. Results revealed that pipe risers were more effective in detaining sediment load within the berm. It should be noted that the sediment routing module programmed into the toolbox is based upon a simple empirical equation, where fine sediment particles like silt and clay are not settled at all within the berm thereby yielding lower sediment removal efficiency for blind inlet compared to pipe risers. This is a limitation of this study. Also, the results obtained from the toolbox need to be validated with real experimental data collected to assess the accuracy of the toolbox.

\section{Acknowledgments}

The authors acknowledge the financial support from Ontario Ministry of Agriculture, Food and Rural Affairs (OMAFRA), Natural Sciences and Engineering Research Council (NSERC), and the University of Guelph. A special thanks to Mr. Rishabh Jain and Mr. Deepak Jain for helping with programming during the development of the toolbox.

\section{References}

Ayars, J. E., \& Evans, R.G. (2015). SUBSURFACE DRAINAGE-WHAT'S NEXT? Irrigation and Drainage, 64, 378-392. https://doi.org/10.1002/ird.1893

Babin, N., Mullendore, N. D., \& Prokopy, L. S. (2016). Using social criteria to select watersheds for non-point source agricultural pollution abatement projects. Land Use Policy, 55, 327-333. https://doi.org/10.1016/j. landusepol.2015.06.021

Bagnold, R. (1966). An approach to the sediment transport problem from general physics. Prof. Paper 422-J. US Geological Survey, Reston, VA., 1966.

Ball Coelho, B., Lapen, D., Murray, R., Topp, E., Bruin, A., \& Khan, B. (2012). Nitrogen loading to offsite waters from liquid swine manure application under different drainage and tillage practices. Agricultural Water Management, 104, 40-50. https://doi.org/10.1016/j.agwat.2011.11.014

Ball Coelho, B., Murray, R., Lapen, D., Topp, E., \& Bruin, A. (2012). Phosphorus and sediment loading to surface waters from liquid swine manure application under different drainage and tillage practices. Agricultural Water Management, 104, 51-61. https://doi.org/10.1016/j.agwat.2011.10.020

Borah, D.K., Arnold, J.G., Bera, M., Krug, E.C., \& Liang, Xin-Zhong. (2007). Storm Event and Continuous Hydrologic Modeling for Comprehensive and Efficient Watershed Simulations. Journal of Hydrologic Engineering, 12(6), 605-616. https://doi.org/10.1061/(ASCE)1084-0699(2007)12:6(605) 
Cho, J., Park, S., \& Im, S. (2008). Evaluation of Agricultural Nonpoint Source (AGNPS) model for small watersheds in Korea applying irregular cell delineation. Agricultural Water Management, 95(4), 400-408. https://doi.org/10.1016/j.agwat.2007.11.001

Choi, K. S., \& Blood, E. (1999). Modeling developed coastal watersheds with the Agricultural Non-Point Source model. Journal of the American water Resources Association, 35(2), 233-244.

Daggupati, P., Douglas-Mankin, K.R., \& Sheshukov, A. Y. (2013). Predicting ephemeral gully location and length using topographic index models. Transactions of the American Society of Agricultural and Biological Engineers, 56(4), 1427-1440. https://doi.org/10.13031/trans.56.10087

Daggupati, P., Douglas-Mankin, K.R., Sheshukov, A. Y., Barnes, P. L., \& Devlin, D.L. (2011). Field-level targeting using SWAT: mapping outputs from HRUs to fields and assessing limitations of GIS input data. Transactions of the American Society of Agricultural and Biological Engineers, 54(2), 501-514.

Das, S., Rudra, R. P., Goel, P. K., Gharabaghi, B., \& Gupta, N. (2006). Evaluation of AnnAGNPS in cold and temperate.pdf. Water Science and Technology, 53(2), 263-270. https://doi.org/10.2166/wst.2006.060

Diebel, M. W., Maxted, J. T., Nowak, P. J., \& Vander Zanden, M. J. (2008). Landscape planning for agricultural nonpoint source pollution reduction I: A geographical allocation framework. Environmental Management, 42(5), 789-802. https://doi.org/10.1007/s00267-008-9186-3

Dile, Y. T., Daggupati, P., George, C., Srinivasan, R., \& Arnold, J. (2016). Introducing a new open source GIS user interface for the SWAT model. Environmental Modelling and Software, 85, 129-138.

Dillaha, T. A., Sherrard, J. H., Lee, D., Mostaghimi, S., \& Shanholtz, V. O. (1988). Evaluation of Vegetative Filter Strips as a Best Management Practice for Feed Lots. Journal (Water Pollution Control Federation), 60(7), 1231-1238. https://doi.org/10.2307/25043629

Eckhardt, K., \& Arnold, J. G. (2001). Automatic calibration of a distributed catchment model. Journal of Hydrology, 25l(1-2), 103-109. https://doi.org/10.1016/S0022-1694(01)00429-2

Feyereisen, G. W., Francesconi, W., Smith, D. R., Papiernik, S. K., Krueger, E. S., \& Wente, C. D. (2015). Effect of replacing surface inlets with blind or gravel inlets on sediment and phosphorus subsurface drainage losses. Journal of Environmental Quality, 44(2), 594-604.

Fiener, P., Auerswald, K., \& Weigand, S. (2005). Managing erosion and water quality in agricultural watersheds by small detention ponds. Agriculture, Ecosystems and Environment, 110(3-4), 132-142. https://doi.org/10.1016/j.agee.2005.03.012

Fraga, I., Charters, F. J., Sullivan, A. D. O., \& Cochrane, T. A. (2016). A novel modelling framework to prioritize estimation of non-point source pollution parameters for quantifying pollutant origin and discharge in urban catchments. Journal of Environmental Management, 167, 75-84. https://doi.org/10.1016/j.jenvman. 2015.11.003

Fu, Y., Ruan, B., \& Gao, T. (2013). Watershed Agricultural Non-Point Source Pollution Management. Polish Journal of Environmental Studies, 22(2), 367-375.

Gharabaghi, B., Rudra, R. P., \& Goel, P. K. (2006). Effectiveness of vegetative filter strips in removal of sediments from overland flow. Water Quality Research Journal of Canada, 41(3), 275-282.

Ginting, D., Moncrief, J. F., \& Gupta, S. C. (2000). Runoff, Solids, and Contaminant Losses into Surface Tile Inlets Draining Lacustrine Depressions. Journal of Environment Quality, 29(2), 551-560. https://doi.org/10. 2134/jeq2000.00472425002900020024x

Golmohammadi, G., Prasher, S. O., Madani, A., Rudra, R. P., \& Youssef, M. A. (2016). SWATDRAIN, a new model to simulate the hydrology of agricultural Lands, model development and evaluation. Biosystems Engineering, 141,31-47. https://doi.org/10.1016/j.biosystemseng.2015.11.003

Golmohammadi, G., Rudra, R., Dickinson, T., Goel, P., \& Veliz, M. (2017). Predicting the temporal variation of flow contributing areas using SWAT. Journal of Hydrology, 547, 375-386. https://doi.org/10.1016/j.jhydrol. 2017.02.008

Gonzalez, J. M., Smith, D. R., Livingston, S., Warnemuende-Pappas, E., \& Zwonitzer, M. (2016). Blind inlets: conservation practices to reduce herbicide losses from closed depressional areas. Journal of Soils and Sediments, 16(7), 1921-1932. https://doi.org/10.1007/s11368-016-1362-0 
Gupta, A.K., Rudra, R. P., Gharabaghi, B., Daggupati, P., Goel, P.K., Shukla, R. (2018). Predicting the Impact of Drainage Ditches upon Hydrology and Sediment Loads Using KINEROS 2 Model: A Case Study in Ontario. Canadian Biosystems Engineering, 60, 1.1-1.15. https://doi.org/10.7451/CBE.2018.60.1.1

Her, Y., Chaubey, I., Frankenberger, J., \& Jeong, J. (2017). Implications of spatial and temporal variations in effects of conservation practices on water management strategies. Agricultural Water Management, 180, 252-266. https://doi.org/10.1016/j.agwat.2016.07.004

Her, Y., Chaubey, I., Frankenberger, J., \& Smith, D. (2016). Effect of conservation practices implemented by USDA programs at field and watershed scales. Journal of Soil and Water Conservation, 71(3), 249-266. https://doi.org/10.2489/jswc.71.3.249

Jianchang, L., Luoping, Z., Yuzhen, Z., Huasheng, H., \& Hongbing, D. (2008). Validation of an agricultural non-point source (AGNPS) pollution model for a catchment in the Jiulong River watershed, China. Journal of Environmental Sciences, 20(5), 599-606. https://doi.org/10.1016/S1001-0742(08)62100-2

Kalin, L., \& Hantush, M. M. (2006). Hydrologic Modeling of an Eastern Pennsylvania Watershed with NEXRAD and Rain Gauge Data. Journal of Hydrologic Engineering, 11(6), 555-569. https://doi.org/10.1061/

King, K. W., Williams, M. R., Macrae, M. L., Fausey, N. R., Frankenberger, J., Smith, D. R., Kleinman, P. J. A., \& Brown, L.C. (2015). Phosphorus Transport in Agricultural Subsurface Drainage: A Review. Journal of Environment Quality, 44(2), 467-485. https://doi.org/10.2134/jeq2014.04.0163

Knisel, W. G. (1980). CREAMS: A Field-Scale Model for Chemicals, Runoff and Erosion from Agricultural Management Systems. U.S. Department of Agriculture, Conservation Report No. 26, 640 Pp., (26), 1980.

Kyoung, J. L., Engel, B. A., Tang, Z., Choi, J., Kim, K. S., Muthukrishnan, S., \& Tripathy, D. (2005). Automated Web GIS based hydrograph analysis tool, WHAT. Journal of the American Water Resources Association, 41(6), 1407-1416. https://doi.org/10.1111/j.1752-1688.2005.tb03808.x

Li, S., Bhattarai, R., Cooke, R. A., Rendall, T., Dahal, V., \& Kalita, P. K. (2017). Assessment of surface inlets performance on sediment transport to subsurface drainage system. Applied Engineering in Agriculture, 33(2), 217-224. https://doi.org/10.13031/aea.12039

Liu, X., Zhang, X., \& Zhang, M. (2008). Major Factors Influencing the Efficacy of Vegetated Buffers on Sediment Trapping: A Review and Analysis. Journal of Environment Quality, 37(5), 1667-1674. https://doi.org/10.2134/jeq2007.0437

Liu, Y. (2013). SWAT Modelling of Agricultural BMPs and Analysis of BMP Cost Effectiveness in the Gully Creek Watershed.

Lyne, V., \& Hollick, M. (1979). Stochastic time-variable rainfall-runoff modelling. Institute of Engineers Australia National Conference, 1979(January 1979), 89-93.

McCuen, R. H. (1982). A guide to hydrologic analysis using SCS methods. Englewood Cliffs, N.J.: Prentice-Hall, 1982.

McKague, K. (2017). Upper Thames River Conservation Authority report card 2017. Upper Thames River Conservation Authority, London Ontario., 20 Pp., 24. https://doi.org/10.1002/ejoc.201200111

Meng, Y., Wang, H., Chen, J., \& Zhang, S. (2014). Modelling hydrology of a single bioretention system with HYDRUS-1D. The Scientific World Journal, 2014. https://doi.org/10.1155/2014/521047

Miklanek, P., Pekarova, P., Konicek, A., \& Pekar, J. (2004). Research Note: Use of a distributed erosion model (AGNPS) for planning small reservoirs in the Upper Torysa basin. Hydrology and Earth System Sciences, 8(6), 1186-1192. https://doi.org/10.5194/hess-8-1186-2004

Mohammed, H., Yohannes, F., \& Zeleke, G. (2004). Validation of agricultural non-point source (AGNPS) pollution model in Kori watershed, South Wollo, Ethiopia. International Journal of Applied Earth Observation and Geoinformation, 6(2), 97-109. https://doi.org/10.1016/j.jag.2004.08.002

Parajuli, P.B, Yoo, K. ., \& Shannon, D. A, \& Jeon, W. J. (2007). Application of wepp and agnps to a cattle grazing pasture with poultry litter application as a fertilizer. Journal of Environmental Hydrology, 15(November), 1-11.

Park, Y. S., Engel, B. A., Frankenberger, J., \& Hwang, H. (2015). A web-based tool to estimate pollutant loading using LOADEST. Water (Switzerland), 7(9), 4858-4868. https://doi.org/10.3390/w7094858 
Runkel, B. R. L., Crawford, C. G., \& Cohn, T. A. (2004). Load estimator ( loadest ): a fortran program for estimating constituent loads in streams and rivers. US Geological Survey Techniques and Methods Book 4, Chapter A5, 2004.

Sebti, S., \& Rudra, R. (2010). An approach to evaluate vegetative filter strip in watershed scale. Applied Engineering in Agriculture, 26(5), 817-826.

Shang, F., Ren, S., Yang, P., Li, C., Xue, Y., \& Huang, L. (2016). Modeling the Risk of the Salt for Polluting Groundwater Irrigation with Recycled Water and Ground Water Using HYDRUS-1 D. Water, Air, and Soil Pollution, 227(6). https://doi.org/10.1007/s11270-016-2875-2

Šimůnek, J., Sejna, M. \& van Genuchten, M. T. (1998). Hydrus-1d software package for simulating the one-dimensional movement of water heat and multiple solutes in variably saturated media, version 2.0. IGWMC-TPS-70. Colorado School of Mines, Golden, Colorado, USA.

Smith, D. R., \& Livingston, S. J. (2013). Managing farmed closed depressional areas using blind inlets to minimize phosphorus and nitrogen losses. Soil Use and Management, 29(SUPPL.1), 103-113. https://doi.org/10.1111/j.1475-2743.2012.00441.x

Smith, D. R., Francesconi, W., Livingston, S. J., \& Huang, C. hua. (2015). Phosphorus losses from monitored fields with conservation practices in the Lake Erie Basin, USA. Ambio, 44(2), 319-331. https://doi.org/10.1007/s13280-014-0624-6

Smith, D. R., Livingston, S. J., Zuercher, B. W., Larose, M., Heathman, G. C., \& Huang, C. (2008). Nutrient losses from row crop agriculture in Indiana. Journal of Soil and Water Conservation, 63(6), 396-409. https://doi.org/10.2489/jswc.63.6.396

Sprague, L. A., \& Gronberg, J. A. M. (2012). Relating Management Practices and Nutrient Export in Agricultural Watersheds of the United States. Journal of Environment Quality, 41, 1939-1950. https://doi.org/10.2134/jeq2012.0073

Srivastava, P., Gupta, A. K., \& Kalin, L. (2010). An ecologically-sustainable surface water withdrawal framework for cropland irrigation: A case study in Alabama. Environmental Management, 46(2), 302-313. https://doi.org/10.1007/s00267-010-9537-8

Tomer, M. D., Wilson, C. G., Moorman, T. B., Cole, K. J., Heer, D., \& Isenhart, T. M. (2010). Source-Pathway Separation of Multiple Contaminants during a Rainfall-Runoff Event in an Artificially Drained Agricultural Watershed. Journal of Environment Quality, 39(3), 882-895. https://doi.org/10.2134/jeq2009.0289

USDA-NRCS. (2018). CONSERVATION PRACTICE STANDARD, Code 620, "Underground Outlet" Retrieved August 28, 2018, from https://www.nrcs.usda.gov/wps/portal/nrcs/detail/national/technical/econ/ data/?cid=nrcseprd 1298864

USDA-NRCS. (2018). CONSERVATION PRACTICE STANDARD, Code 638, "Water and Sediment Control Basin". Retrieved August 28, 2018, from https:/www.nrcs.usda.gov/wps/portal/nrcs/detail/national/ technical/econ/data/?cid=nrcseprd 1298864

Wang, G., Chen, L., Huang, Q., Xiao, Y., \& Shen, Z. (2016). The influence of watershed subdivision level on model assessment and identification of non-point source priority management areas. Ecological Engineering, 87, 110-119. https://doi.org/10.1016/j.ecoleng.2015.11.041

Wilson, B. N., \& Barfield, B. J. (1984). A Sediment Detention Pond Model. Transactions of the American Society of Agricultural Engineers, 27(5), 1339-1344.

Wilson, R. (2016). Ausable Bayfield Conservation Authority watershed report card 2016. Ausable Bayfield Conservation Authority, Exeter Ontario. 32 Pp.

Young, R. A., Onstad, C. A., Bosch, D. D., \& Anderson, W. P. (1989a). AGNPS: A nonpoint-source pollution model for evaluating agricultural watersheds. Journal of Soil and Water Conservation, 44(2), 168-173. https://doi.org/citeulike-article-id:13481122

\section{Copyrights}

Copyright for this article is retained by the author(s), with first publication rights granted to the journal.

This is an open-access article distributed under the terms and conditions of the Creative Commons Attribution license (http://creativecommons.org/licenses/by/4.0/). 